\title{
STAT5A wt Allele
}

National Cancer Institute

\section{Source}

National Cancer Institute. STAT5A wt Allele. NCI Thesaurus. Code C52155.

Human STAT 5A wild-type allele is located in the vicinity of $17 q 11.2$ and is approximately $24 \mathrm{~kb}$ in length. This allele, which encodes signal transducer and activator of transcription $5 \mathrm{~A}$ protein, is involved in both cytokine and growth factor-stimulated signaling and suppression of apoptosis. 